\title{
Dijital Hikâye Uygulamalarının Öğrencilerin Motivasyonları Üzerindeki Etkisinin Bazı Moderatör Değişkenler Açısından İncelenmesi: Meta Analiz Çalışması
}

\author{
Doç. Dr. Nurullah Şahin \\ A ̆̆r İbrahim Çeçen Üniversitesi, Ĕ̆itim Fakültesi \\ Türkçe ve Sosyal Bilimler Ĕ̆itimi Bölümü \\ nsahin.86@gmail.com
}

Öz

Öğrencilerin problem çözme, işbirlikli çalışma, kendini etkili bir şekilde ifade edebilme, yazma, eleştirel düşünme, dijital okuryazarlık, teknolojiyi etkin kullanma, kendi öğrenmelerini gerçekleştirme gibi üst düzey becerilerini geliştiren ve doğası gereğ yapılandırmacı anlayışa uygun bir yöntem olarak ön plana çıkan dijital hikâye anlatımı; son dönemlerde eğitim öğretim süreçlerinin vazgeçilmez öğretim materyali olarak dikkat çekmektedir. İlgili alanyazın tarandığında dijital hikâye kullanımının konu edinildiği onlarca çalışmaya rastlanılabilir. Bu çalışmaların neredeyse tamamının ifade ettiği sonuçlardan biri de dijital hikâye uygulamalarının öğrencilerin akademik başarı, tutum, motivasyon, direnç gibi durumlarını pozitif yönde etkilemesidir. Bu araştırmada, metaanaliz kullanılarak, dijital hikâye uygulamalarının öğrencilerin motivasyonları üzerindeki etkisinin araştırıldığı deneysel çalışmalardan elde edilen sonuçların sentezlenmesi ve böylelikle daha genel geçer sonuçlara ulaşılması amaçlanmıştır. İlgili deneysel çalışmalara; Web of Science, ERIC, EBSCOhost, ULAKBİM TR Dizin, Google Akademik ve YÖK Tez veri tabanlarında; "dijital hikâye, dijital öykü, motivasyon, digital story, digital storytelling, motivation" anahtar kelimeleri kullanılarak ulaşılmıştır. Analizlerin Comprehensive Meta Analysis (CMA) programı ile yapıldığı çalışma, \%95 güven aralığında rastgele etkiler modeline göre gerçekleştirilmiş ve ortalama etki büyüklüğü 2,070 olarak hesaplanmıştır. $\mathrm{Bu}$ sonuç, dijital hikâye uygulamalarının öğrencilerin motivasyonları üzerinde mükemmel düzeyde olumlu bir etki oluşturduğunu göstermektedir. Dijital hikâye ve diğer öğretim yöntemlerinin kullanıldığı öğrenme öğretme süreçlerinde öğrencilerin motivasyonları arasındaki farklılıklar yayın türü ve öğretim kademesi moderatör değişkenlerine göre analiz edilmiştir. Elde edilen sonuçlar her iki moderatör değişkenin de çalışmaların etki büyüklükleri üzerinde anlamlı bir fark oluşturduğunu göstermiştir.

Anahtar Kelimeler: Dijital hikâye, dijital öykü, motivasyon, meta-analiz, eğitim.

\section{Investigation of the Effect of Digital Story Activities on Students' Motivations in Terms of Some Moderator Variables: Meta-Analysis Study}

\section{Abstract}

Digital storytelling, which stands out as a method suitable for constructivist approach by its nature, has attracted attention as an indispensable teaching material of education 
processes in recent years as it develops students' high-level skills such as problem-solving, collaborative working, effective self-expression, writing, critical thinking, digital literacy, using technology effectively, realizing their own learning. When the relevant literature is reviewed, dozens of studies on the use of digital storytelling can be found. One of the results expressed by almost all of these studies is that digital storytelling practices positively affect students' academic achievement, attitude, motivation, and resistance. In this study, using meta-analysis, it was aimed to synthesize the results obtained from experimental studies that investigated the effect of digital storytelling practices on students' motivation, and thus to reach more common results. Relevant experimental studies were found by using the keywords "dijital hikâye, dijital öykü, motivasyon, digital story, digital storytelling, motivation" on Web of Science, ERIC, EBSCOhost, ULAKBIMM TR Index, Google Academic, and YÖK Thesis databases. The study, in which the analyzes were carried out with the Comprehensive Meta Analysis (CMA) software, was carried out according to the random effects model at a 95\% confidence interval and the average effect size was calculated as 2,070. This result shows that digital story applications have an excellent positive effect on students' motivation. The differences between students' motivations in learning-teaching processes using digital stories and other teaching methods were analyzed according to the moderator variables of the type of publication and the teaching level. The results obtained showed that both moderator variables made a significant difference in the effect sizes of the studies.

Keywords: Digital story, digital storytelling, motivation, meta-analysis, education. 


\section{GİRIŞ}

\section{Dijital Hikâye ve Motivasyon}

Yazılı kaynakların ortaya çıkmasından çok daha önceki dönemlerde bile var olduğu bilinen hikâye anlatma geleneği, gelişen ve ilerleyen teknoloji ile birlikte çok daha farklı zeminlerde ve boyutlarda karşımıza çıkmaya başlamıştır. Dijital ortama taşınan hikâye anlatmanın hedef kitle üzerindeki etkisinin de böylelikle artacağ düşünülmüştür. Nitekim dijital ortama taşınan hikâye anlatımı; yazılı, görsel ve işitsel iletişime imkân sunmakta ve böylelikle verilmek istenilen mesajın daha kalıcı hâle gelmesine yardımcı olmaktadır. Geleneksel hikâye anlatımının çoklu ortam elemanlarıyla birleştirilmesi sonucu ortaya çıkan dijital hikâye anlatımı; kişisel hikâyeler, tarihteki olaylar gibi konularda bilgi aktarımının sağlanması için metin, müzik, grafik, seslendirme, video gibi ögelerin birleştirilerek oluşturulduğu birkaç dakikalık hikâyelerdir (Balaman, 2016; Banazewski, 2005; İnceelli, 2005; Jakes \& Brennan, 2005; Meadows, 2003; Mellon, 1999; Robin, 2006).

Son dönemlerde farklı disiplinlerdeki kullanım alanları oldukça artan dijital hikâye; genel olarak multimedya araçları veya kaynakları kullanılarak bilginin paylaşıldığı kısa, bireysel ve çoklu ortam hikâyeleri olarak tanımlanmaktadır (Meadows, 2003 ve Yüksel, 2011). Reinders (2011) ise, dijital hikâyeyi geleneksel hikâye anlatımının elektronik biçimi olarak değerlendirir ve metin, ses, müzik, video, fotoğraflar, ekran görüntüleri, diğer resimler ve bunlardan başka dijital medya ögeleri gibi unsurlardan en az ikisinin mutlaka dijital hikâyelerde bulunması gerektiğini ifade eder.

Kişisel dijital öyküler, eğitici dijital öyküler ve tarihî dijital öyküler olmak üzere üç türünden bahsedilen dijital hikâyenin ögeleri şunlardır (Lambert, 2006):

1. Bakış Açısı

2. Etkileyici Bir Soru

3. Duygusal İçerik

4. Ekonomi

5. Seslendirme

6. Müzik

7. Hiz Denetimi / Ritim

$\mathrm{Bu}$ bileşenlerden ilk dördü hikâyenin içeriği ve yazımı ile ilgili iken diğerleri hikâyenin oluşumu ile ilgilidir. Robin ve Pierson (2005) ise, dijital hikâye anlatımının eğitsel amaçlar için kullanımını sağlamak adına bu 7 bileşene "Hikâye Amacı", "Görüntü Kalitesi" ve "İyi Dilbilgisi ve Dil Kullanımı" bileşenlerini ekleyerek 10 bileşenden bahsetmişlerdir.

Hikâyelerin belli bir amaç için dijital olarak anlatılmasını ifade eden dijital hikâyenin temelleri 1970 ve 1980 'li yıllarda ABD'de atılmıştır ve o zamandan beri öğretmenler ve öğrenciler tarafından kullanılmaktadır. 1994'te San Fransisco'da kurulan Dijital Medya Merkezi kurucularından biri olan Joe Lambert'in öncülük ettiği araştırmalar ile gittikçe yaygınlık kazanmıştır. 1998'de Berkeley'e taşınan Dijital Medya Merkezi, Dijital Hikâye Anlatımı Merkezi'ne dönüşmüş ve çok daha sonraki dönemlerde dijital hikâye anlatımı ile ilgili becerileri öğreten birimlerin temelini oluşturarak ululararası birçok kurum ve kuruluş ile birlikte çalışmıştır (Center for Digital Storytelling, 2020). Dijital hikâye ile ilgili önemli kuruluşlardan bir diğeri ise, Bernerd Robin tarafından Houstan Üniversitesi'nde kurulan ve 
dijital hikâyeyi eğitsel amaçlarla kullanmayı hedefleyen Eğitimde Dijital Hikâyelerin Kullanımı Merkezi (The Educational Uses of Digital Storytelling) isimli merkezdir. 1990'lardan itibaren Dijital hikâye kullanımı gün geçtikçe artmıştır. Türkiye'de ise son dönemlerde kullanım sıklığı artan dijital hikâye uygulamaları, ekonomik ve kolay ulaşılabilir olması sebebiyle eğitim öğretim süreçlerinde çok daha fazla tercih edilen bir öğretim materyali konumuna gelmiştir (Bull \& Kajder, 2004; Lambert, 2003).

Öğretim materyali olarak kullanılacak dijital hikâyelerin 2 ila 10 dakika arasında bir uzunluğa, en az bir sayfalık bir senaryoya ve 20-25 arasında bir fotoğrafa sahip olması beklenir (Haliloğlu Tatll, 2016; Jakes \& Brennan, 2005; Menezes, 2012)

Dijital hikâye sürecinin en önemli unsurlarından biri teknolojidir. "Teknoloji, insan hayatını kolaylaştırmak, düzene koymak, onu daha anlamlı kılmak için vardır, gereklidir ve vaz geçilmezdir" (Alyılmaz, 1997, s. 33). Günümüz teknolojisi, öğrencilere kendi hikâyelerini oluşturma fırsatı vermektedir ve bu eğitim öğretim faaliyetleri açısından düşünüldüğünde öğrencinin duyuşsal becerileri üzerinde çok olumlu etkiler oluşturabilmektedir. Dijital hikâye yöntemi öğretmenler ve öğrenciler için etkili bir eğitsel araç olmakla birlikte öğrencilerin bilgiyi organize etme, orijinal fikirler oluşturma, kendi duygu ve düşüncelerini etkili bir şekilde ifade etme, eleştirel düşünme, yazma, dijital okuryazarlık, teknoloji okuryazarlığı, problem çözme gibi üst düzey becerilerini geliştirmelerine olanak ve ortam oluşturur (Chung, 2007; Dörner, Grimm \& Abawi, 2002; Frazel, 2010; Hung, Hwang \& Huang, 2012; Ohler, 2013; Robin, 2006).

Günümüzde bilim ve teknoloji alanında yaşanan gelişmeler ve değişimler, yaşamın her alanında olduğu gibi eğitim alanında da önemli değişiklikleri beraberinde getirmiştir. $\mathrm{Bu}$ değişiklikleri eğitim öğretim süreçlerinde kullanılan araç, gereç, materyal ve yöntemteknikler üzerinde açıçca görmek mümkündür. Bu bağlamda karşımıza çıkan önemli yöntemlerden biri de dijital hikâye yöntemidir. Dijital hikâye anlatımı farklı birçok alanda kullanılmakla beraber eğitsel amaçları gerçekleştirmek için eğitim öğretim süreçlerinde de kullanılmaya başlanmıştır. Doğası gereği çağdaş eğitim anlayışları açısından uygun bir yöntem olan dijital hikâye farklı branş öğretmenleri tarafından her yaştan ve her kademeden öğrencilerin öğrenmeleri için kullanılan popüler bir pedagojik araç hâline gelmiştir (Garcia \& Rossiter, 2010 ve Göçen, 2014). "Dijital öyküleme yöntemi günümüz dijital nesline kalıcı ve verimli bir eğitim sunabilmek, onları bu eğitime aktif bir katılımla dâhil edebilmek, eğitim ve öğretimde sürekliliği ve canlılı̆̆ı devamlı kılmak ve yaşadığımız yüzyılın, yetiştirilen nesilden beklediği özellikler ile öğrencileri buluşturmak için kullanılabilecek bir yöntemdir" (Çakıcı, 2018, s. 23).

Öğrencinin aktifleşmesini sağlayarak öğrenci merkezli bir eğitim modeli oluşturmayı hedefleyen dijital hikâye yöntemi, eğitim öğretim süreçlerinde kullanıldığında öğrenci katılımını artıran, derin ve proje tabanlı öğrenmeyi sağlayan, öğrenmeyi daha kalıcı hâle getiren ve öğrenme ortamına teknoloji entegrasyonunu sağlayan önemli bir yöntem olarak karşımıza çıkmaktadır (Barret, 2009 ve Çakıcı, 2018).

Howell ve Howell (2003) eğitim öğretim süreçlerinde dijital hikâyeleri kullanmanın yaralarını şöyle sıralamaktadır:

1. Öğrencilerin duygularını, düşüncelerini, fikirlerini, tecrübelerini ve kültürlerini eğlenceli bir biçimde başkalarıyla paylaşma ortamı oluşturur. 
2. Dijital hikâyeleri kullanan öğrenciler kendi öğrenmelerini gerçekleştirebilme bağlamında önemli bir mesafe kat eder.

3. Öğrencilerin bağımsız ve aktif olmaları noktasında dijital hikâyeler önemli bir yöntemdir.

4. Öğrencilerin dil gelişimi ve teknolojik araçları kullanma noktasındaki yeterlilikleri dijital hikâyeler aracılığıyla artar.

5. Medyayı eleştirel bir gözle inceleme becerisi kazanırlar.

6. Öğrencilerin öğrenme motivasyonlarını artırmada, dijital hikâye anlatımının katkısı çok büyüktür.

7. Öğrencilerin yaratıcı yazma becerileri artar.

8. Öğrencinin yazma, akıcı konuşma ve eleştirel okuma gibi konulardaki dil kullanım becerisi gelişir.

Tüm bunlar dijital hikâye kullanımının eğitim öğretim süreçlerinde öğrenciler üzerindeki olumlu etkilerini göstermesi bakımından da dikkate değerdir.

Dijital hikâye yöntemiyle ilgili yapılan çalışmaların birçoğunda bu yöntemin öğrencilerin derse karşı olan ilgilerini, tutumlarını ve motivasyonlarını artırdığı vurgulanmaktadır. Kendi hikâyelerini yazma ve bunları başkalarıyla paylaşma fırsatını bulan öğrencilerin derse karşı olumlu tutum ve motivasyona sahip olması da doğaldır.

\section{Meta-Analiz}

"Meta-analitik etki analizi kısaca meta-analiz, daha önceden yapılmış bağımsız çalışmaların sonuçlarının istatistiksel olarak bütünleştirilmesi için kullanılan istatistiksel yöntem ve tekniklerdir. Çok sayıda farklı çalışmanın sonuçlarını özetlemede kullanılan analitik bir teknik olarak bakılsa da, bir araştırma yapma yöntemi olarak da düşünülmektedir" (Bakioğlu \& Özcan, 2016, s. iii). Aşağıda verilen bazı tanımların konunun anlaşılmasına katkı sağlayacağı düşünülmektedir:

"Meta-analiz, bireysel çalışmalardan elde edilen deneysel bulguların birleştirilmesi, sentezlenmesi ve yorumlanması amaciyla kullanılan istatistiksel prosedürler uygulamasıdır" (Wolf, 1986'dan akt. Bakioğlu \& Özcan, 2016, s. 5).

"Birçok küçük bireysel çalışma sonuçlarının bir ya da birden daha fazla istatistiksel yöntem kullanılarak birleştiren ve daha fazla bilgi veren bir analiz tekniğidir" (Olkin, 1999'dan akt. Bakioğlu \& Özcan, 2016, s. 5).

Temel olarak analizlerin analizi ya da analizlerin birleştirilmesi gibi anlamlara gelen meta-analizin kullanım alanları sağlık bilimleri ile başlayıp zamanla birçok bilim dalını içine alacak kadar yaygınlaşmıştır. Duruma Türkiye perspektifinden bakıldığında ise kaynak yetersizlikleri ve bazı yanlış görüşler gibi sebeplerden ötürü meta-analizin Türkiye'de arzu edilen kullanım alanına hâlâ ulaşamadığı görülmektedir. (Dinçer, 2014; Lipsey \& Wilson, 2001; Schulze, 2007).

Tip bilimleri başta olmak üzere sosyal bilimler ve eğitim bilimleri gibi bilim alanlarında da gittikçe yaygın bir şekilde kullanılmaya başlayan meta-analiz yöntemi, tüm dünyada olduğu gibi Türkiye'de de gün geçtikçe yaygınlaşmakta ve meta-analizle ilgili çeşitli yayınlar literatürdeki yerini almaya başlamaktadır (Bakioğlu \& Özcan, 2016; Dinçer, 2014). 


\section{Araștırmanın Amacı}

Alanyazında dijital hikâyenin öğrencilerin motivasyonları üzerindeki etkisini araştıran deneysel çalışmalar azımsanmayacak kadar yer bulmasına rağmen bu çalışmalardan elde edilen analiz sonuçlarını birleştirerek yeni yorumların ve araştırmaların yapılmasını sağlayacak meta analiz çalışmalarına rastlanılmamıştır. Bu sebeple, dijital hikâye temelli etkinliklerin kullanılarak işlendiği derslerin diğer öğretim yöntemleri ile işlenen derslere göre öğrencilerin motivasyonları üzerindeki etkisi ile ilgili daha güvenilir ve genel yargılara ulaşabilmek amacıyla böyle bir meta-analiz çalışmasının yapılmasına karar verilmiştir. Bu bağlamda, bu meta analiz çalışmasının amacı; dijital hikâye temelli etkinlikler kullanılarak işlenen derslerin öğrencilerin motivasyonları üzerindeki etkisini belirlemektir, şeklinde ifade edilmiştir. Bu temel amaç düzleminde aşağıdaki araştırma problemlerine cevap aranmıştır:

1. Dijital hikâye uygulamaları ile işlenen dersler ile diğer öğretim yöntem tekniklerinin kullanılarak işlendiği derslerde, öğrencilerin motivasyonları arasında fark var mıdır?

2. Dijital hikâye uygulamaları ile işlenen dersler ile diğer öğretim yöntem tekniklerinin kullanılarak işlendiği derslerde, öğrencilerin motivasyonları arasındaki fark, meta analize dâhil edilen çalışmaların yayın türüne (makale-tez) göre anlamlı olarak farklılaşmakta mıdır?

3. Dijital hikâye uygulamaları ile işlenen dersler ile diğer öğretim yöntem tekniklerinin kullanılarak işlendiği derslerde, öğrencilerin motivasyonları arasındaki fark, meta analize dâhil edilen çalışmaların örneklem gruplarında yer alan öğrencilerin öğrenim kademelerine (anaokulu, ilkokul, ortaokul, lise ve üniversite) göre anlamlı olarak farklılaşmakta mıdır?

\section{YÖNTEM}

\section{Araştırmanın Modeli}

Bu çalışmada; dijital hikâye temelli etkinliklerin öğrencilerin motivasyonları üzerindeki etkisini araştıran deneysel çalı̧̧malardan elde edilen analizlerin birleştirilmesi amacıyla meta-analiz yöntemi kullanılmıştır. Meta-analiz, belirli bir konuyla ilgili bazı kriterler dikkate alınarak yapılmış çalışmalardan elde edilen nicel verilerin istatistiki yollarla birleştirilmesi ve her bir çalışmaya ait etki büyüklüğü değerinin hesaplanması şeklinde tanımlanabilir (Cohen vd., 2011; Dinçer, 2014; Durlak \& Lipsey, 1991; Hedges, 2007; Salkind, 2007).

\section{Verilerin Toplanması}

Araştırmanin verileri; Web of Science, ERIC, EBSCOhost, ULAKBIM TR Dizin, Google Akademik ve YÖK Tez veri tabanlarında; "dijital hikâye, dijital öykü, motivasyon, digital story, digital storytelling, motivation" anahtar kelimeleri kullanılarak 2020 yılının Haziran ayında toplanmıştır. Yapılan araştırmalar sonucunda dijital hikâye temelli uygulamaların öğrencilerin motivasyonları üzerindeki etkisini araştıran 83 adet çalışmaya ulaşılmıştır.

$\mathrm{Bu}$ meta-analiz çalışması kapsamında incelenen deneysel çalışmalar aşağıdaki kriterlere göre seçilmiştir:

1. Araştırmalar, 2000 - 2020 yılları arasında yapılmış olmalıdır.

2. Araştırmaların yayın dili Türkçe ya da İngilizce olmalıdır. 
3. Araştırmalar, lisansüstü tez ya da bilimsel makale yayın türlerinde yayımlanmış olmalidir.

4. Araştırmalarda kullanılan ölçme araçlarının geçerlik ve güvenirliklerini gösteren bilgilere yer verilmiş olmalıdır.

5. Araştırmalardaki deney gruplarında yer alan öğrencilerle dijital hikâye yöntemi, kontrol gruplarında yer alan öğrencilerle ise diğer öğretim yöntemlerinden biri kullanılarak derslerin işlenmiş olması gerekmektedir.

6. Araştırmalarda dijital hikâye kullanımının öğrencilerin motivasyonları üzerindeki etkisi araştırılmış olmalıdır.

7. Her bir çalışmaya ait etki büyüklüğü değerini hesaplayabilmek için lazım olan istatistiki bilgilere (aritmetik ortalama, standart sapma, örneklem büyüklügüu, ön test - son test korelasyon bilgileri, $\mathrm{p}$ değeri, $\mathrm{p}$ değeri, $\mathrm{u}$ değeri vb.) ilgili çalışmada yer verilmiş olmalıdır.

İlk tarama sonucunda ulaşılan araştırmalar, bu ölçütlere göre tekrar incelenmiş ve 73 çalışma (makale ve tez) bu ölçütleri karşılamadığı için meta-analiz çalışmasının dışında bırakılmıştır. Yapılan elemeler neticesinde, kriterlere uyan toplam 10 farklı araştırma metaanalize alınmıştır. Bu çalışmalardan birinde, dijital hikâyenin birden fazla duruma yönelik motivasyon üzerindeki etkisinin araştırıldığı görülmüştür ve her bir duruma yönelik motivasyon ayrı bir araştırma olarak ele alınıp meta analize dâhil edilmiştir. Böylelikle meta analiz kapsamına alınan bu 10 çalışmadan (makale ve tez) yola çıkılarak, dijital hikâyenin öğrencilerin motivasyonları üzerindeki etkisinin konu edinildiği, toplam 11 farklı araştırmanın meta analizde etki büyüklükleri hesaplanmıştır.

\section{Verilerin Kodlanması}

Meta-analize başlamadan önce, dijital hikâye yöntemi ile ilgili gerçekleştirilen makale ve lisansüstü tez çalışmalarının betimleyici özelliklerini görebilmek için bir kodlama formu oluşturulmuştur. İlgili formda yer verilen bilgiler şöyledir:

1. Araştırmanın başlığı, yazarı, yayınlanma yılı ve yayın türü

2. Araştırmanın gerçekleştirildiği ders alanı

3. Araştırmada çalışılan tema

4. Araştırmada kullanılan desen, yöntem, teknik

5. Araştırmadaki deneysel işlemlerin süresi

6. Araştırmada çalışılan örneklem büyüklüğü

7. Araştırmada çalışılan örneklem grubunun öğrenim düzeyi ve sınıf seviyesi

8. Araştırmada kullanılan ölçme araçlarına ilişkin güvenirlik ve geçerlik bilgilerine yer verilip verilmediği

Kodlama sürecinde hatalı veri girişini önlemek ve yapılan kodlamanın güvenilirliğini sağlamak için ilgili kodlamalar, Türkçe eğitimi alanında doçent iki akademisyen tarafından gerçekleştirilmiş ve süreç sonunda fikir ayrılıklarının olduğu yerlerde ise akademisyenler bir araya gelerek görüş ayrıllğı yaşadıkları kısımlarla ilgili ihtilafları gidermişler ve görüş birliği sağlamışlardır. Yapılan kodlamalar sonunda güvenirlik hesaplanırken Miles ve Huberman (1994)'nın formülünden faydalanılmıştır. Yapılan hesaplamalar neticesinde, gerçekleştirlen kodlamalar \%95 oranında güvenilir bulunmuştur. 


\section{Verilerin Analizi}

Araştırma süresince yapılan hesaplamalar ve analizlerde, Comprehensive Meta Analysis (CMA) yazılımı kullanılmıştır. İlk olarak gerçekleştirilecek meta-analizin modelini (sabit etkiler / rastgele etkiler) belirlemek için homojenlik testi yapılmıştır. Bu doğrultuda meta-analiz çalışması kapsamında incelenen araştırmaların homojenliği $\mathrm{Q}$ değeri, $\mathrm{p}$ değeri ve $I^{2}$ istatistiği ile ayrı ayrı analiz edilmiştir. Her bir çalışmaya ait etki büyüklüğü değeri ve varyans değeri araştırmacı tarafından tek tek hesaplanmış ve CMA programına veri girişi yapilırken etki büyüklüğü ve varyans değerlerinin girilerek ortak etki büyüklüğü değerinin hesaplanabileceği format seçilmiştir. Çalışmalara ait etki büyüklüğü değerleri Cohen's d katsayısı kullanılarak hesaplanmıştır. \%95 güven aralığında gerçekleştirilen tüm hesaplamalar sonucunda ortaya çıkan etki büyüklüklerinin önemi yorumlanırken Cohen $v d$. (2011)'nin ölçütleri dikkate alınmıştır (Dinçer, 2014).

$0 \leq$ Etki büyüklüğü değeri $\leq 0,20$ (Zayıf Etki),

0,21 $\leq$ Etki büyüklüğü değeri $\leq 0,50$ (Küçük Etki),

0,51 $\leq$ Etki büyüklüğü değeri $\leq 1,00$ (Orta Etki),

1,00 > Etki büyüklüğü değeri (Güçlü Etki)

Çalışmanın yayın yanlılığı ise; huni grafiği, Rosenthal'ın güvenli N istatistiği, Orwin'in güvenli N istatistiği ve Mullen, Muellerleile ve Bryant'ın (2001) yayın yanlılığı direnç formülü ile ayrı ayrı analiz edilmiştir.

\section{BULGULAR}

Dijital hikâye uygulamalarının, öğrencilerin motivasyonları üzerindeki etkisini konu edinen bu meta-analiz araştırmasında, 11 çalışma (makale-tez) meta-analize dâhil edilmiştir. İlgili çalışmalara ait tanımlayıcı veriler aşağıdaki tabloda gösterilmiştir:

Tablo 1. Dijital Hikâye Uygulamalarının Öğrencilerin Motivasyonları Üzerindeki Etkisini Araştıran Çalışmalara İlişkin Tanımlayıcı Veriler

\begin{tabular}{llcl}
\hline & & Frekans & Yüzde \\
\hline Çalışma Türü & Makale & 6 & $\% 54,54$ \\
& Lisansüstü Tez & 5 & $\% 45,45$ \\
\hline Çalışmanın Yapıldığı & 2020 & 1 & $\% 9,09$ \\
Yıl & 2018 & 1 & $\% 9,09$ \\
& 2017 & 2 & $\% 18,18$ \\
& 2016 & 1 & $\% 9,09$ \\
& 2014 & 2 & $\% 18,18$ \\
& 2013 & 2 & $\% 18,18$ \\
& 2012 & 2 & $\% 18,18$ \\
\hline Örneklem Grubunun & 5. Sinıf & 3 & $\% 27,27$ \\
Öğrenim Düzeyi & 6. Sinıf & 2 & $\% 18,18$ \\
& 9. Sinıf & 2 & $\% 18,18$ \\
& 10. Sınıf & 1 & $\% 9,09$ \\
& Lisans 2. Sinıf & 2 & $\% 18,18$ \\
& Yabancı Diller Yüksekokulu & 1 & $\% 9,09$ \\
& Hazırlık & & \\
\hline
\end{tabular}




\begin{tabular}{llll}
\hline Örneklem Büyüklüğü & $31 \leq \mathrm{N} \leq 50$ & 2 & $\% 18,18$ \\
& $51 \leq \mathrm{N} \leq 70$ & 2 & $\% 18,18$ \\
& $71 \leq \mathrm{N}$ & 7 & $\% 63,63$ \\
\hline Uygulama Süresi & $1 \leq \mathrm{S} \leq 10$ & 7 & $\% 63,63$ \\
& $11 \leq \mathrm{S} \leq 20$ & 3 & $\% 27,27$ \\
& $21 \leq \mathrm{S}$ & 1 & $\% 9,09$ \\
\hline & Toplam & 11 & $\% 100$ \\
\hline
\end{tabular}

Tablo 1'e göre 5'i lisansüstü öğrenim tezi $(\% 45,45)$ ve 6's1 makale $(\% 54,54)$ yayın türünde olan 11 araştırma yapılan meta-analize alınmıştır. Bunların yayınlandıkları yıllara bakıldığında; 2017, 2014, 2013 ve 2012 yıllarında 2(\%18,18)'şer; 2020, 2018 ve 2016 yıllarında ise $1(\% 9,09)^{\prime}$ er çalışma yapıldığı görülmektedir. Araştırmaların örneklem gruplarının öğrenim düzeyleri incelendiğinde; $3(\% 27,27)$ araştırmanın 5. sınıf öğrencileri, $2(\% 18,18)$ 'şer araştırmanın 6. sınıf, 9. sınıf ve lisans 2 . sınıf öğrencileri, $1(\% 9,09)^{\prime}$ er araştırmanın ise 10. sınıf ve Yabancı Diller Yüksekokulu hazırlık sınıfı öğrencileri ile gerçekleştirildiği görülmektedir. Meta-analiz kapsamında analiz edilen araştırmaların örneklem büyüklükleri incelendiğinde; 11 çalışmanın 7 'sinin $(\% 63,63)$ örneklem grubundaki öğrenci sayısı, $71 \leq \mathrm{N}$ aralığında yer almaktadır. Geriye kalan 4 çalışmanın 2'sinin $(\% 18,18)$ örneklem grubundaki öğrenci sayısı $51 \leq \mathrm{N} \leq 70$ aralığında, diğer 2 'sinin $(\% 18,18)$ örneklem grubundaki öğrenci sayısı ise $31 \leq \mathrm{N}$ $\leq 50$ aralığında yer almaktadır. 11 çalışmanın uygulama süreleri incelediğinde, toplam 7 adet $(\% 63,63)$ çalışmanın uygulama süresinin 1 - 10 hafta arasında bir zaman dilimini kapsadığı görülmektedir. Geriye kalan 4 çalışmanın 3'ünün $(\% 27,27)$ uygulama süresi 11 - 20 hafta arasında yer alırken 1'inin $(\% 9,09)$ uygulama süresi ise 21 haftadan daha fazla bir zaman dilimini kapsamaktadır.

\section{Dijital Hikâye Uygulamalarının Öğrencilerin Motivasyonları Üzerindeki Etkisine İlişkin Bulgular}

Meta-analize alınan 11 araştırmanın her birine ait etki büyüklüğü değerleri araştırmacı tarafından hesaplanmıştır. Çalışmalarda farklı türlerde sunulan istatistiki verilerden (deney ve kontrol gruplarının örneklem büyüklükleri; $t$ değeri; $p$ değeri, $U$ değeri gibi istatistiki bilgiler; ağırlık ortalamalar ve standart sapmalar) faydalanılarak her bir çalışmaya ait etki büyüklüğü değeri hesaplanmıştır ${ }^{1}$. Meta-analiz çalışmasına dâhil edilen araştırmalar vasıtasıyla elde edilen örneklem büyüklüğü aşağıda dikkatlere sunulmuştuır:

Tablo 2. Meta-analize Dâhil Edilen Araştırmalar Vasıtasıyla Elde Edilen Deney ve Kontrol Gruplarının Toplam Örneklem Büyüklükleri

\begin{tabular}{cc} 
Meta-Analize Alınan Çalışmalar Vasıtasıyla Ulaşılan Örneklem Büyüklükleri \\
\hline N (DENEY) & N (KONTROL) \\
453 & 453 \\
\hline
\end{tabular}

Tablo 2'ye göre meta-analiz çalışmasında 453'ü deney grubu 453'ü kontrol grubu olmak üzere toplamda 906 öğrenciye ulaşılmıştır.

Meta-analizin ortalama etki büyüklüğü değeri hesaplanmadan önce çalışmanın yayın yanlılığı tespit edilmiştir. Yapılan meta-analiz çalışmasının yayın yanlılı̆̆1 tespit edilirken

\footnotetext{
${ }^{1}$ Çalışmalara ait etki büyüklügü değerleri hesaplanırken https:/www.psychometrica.de/effect_size.html ve https://campbellcollaboration.org/research-resources/effect-size-calculator.html internet sitelerinden faydalanılmıștır.
} 
huni grafiğiden (funnel plot) faydalanılmıştır. Yapılan analizler neticesinde elde edilen huni grafiği Şekil 1'de gösterilmiştir:

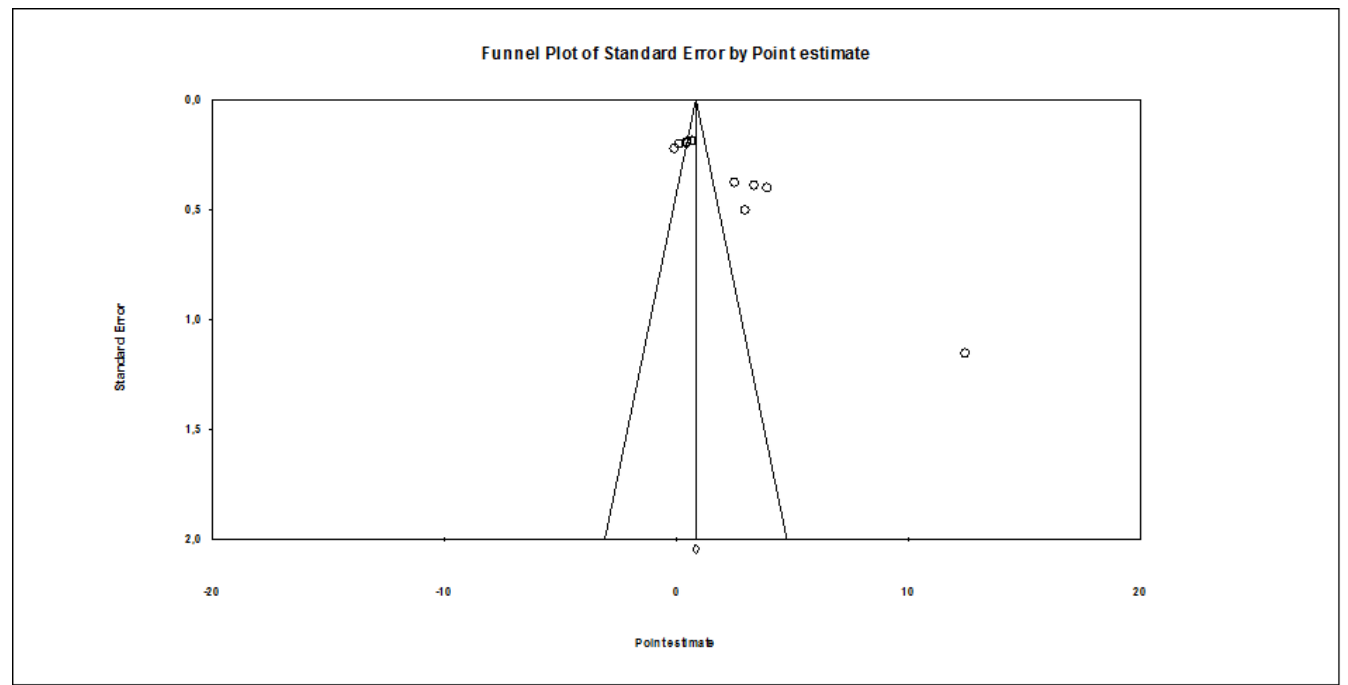

Şekil 1. Yayın Yanlılı̆̆ını Gösteren Huni Grafiği (Funnel Plot) Motivasyon

Şekil 1, meta-analize alınan çalışmaların birçoğunun huni grafiğinin dışında toplandığını göstermektedir. Ayrıca araştırmaların, dikey çizginin sağ ve sol taraflarına dağılımının da simetrik yapıda olmadığı görülmektedir. Tüm bunlar, yapılan meta-analiz çalışmasının yayın yanlılığına sahip olabileceğine işaret etmektedir. Huni grafiği daha simetrik bir görünüme kavuşturabilmek ve yapılan meta-analizin yayın yanlılığı hakkında daha net ifadeler kullanabilmek için Duval ve Tweedie'nin kırp ve doldur yönteminden faydalanılmıştır. Elde edilen sonuçlara göre huni grafiğin simetrik bir yapıya kavuşabilmesi için huninin sol tarafında yayın yanlılığına sebep olan bazı çalışmaları dengeleyebilmek adına huninin sağ tarafına 2 adet yapay çalışma eklenmiştir. Duval ve Tweedie'nin kırp ve doldur yönteminin kullanılmasıyla birlikte ortaya çıkan yeni huni grafiği aşağıda dikkatlere sunulmuştur.

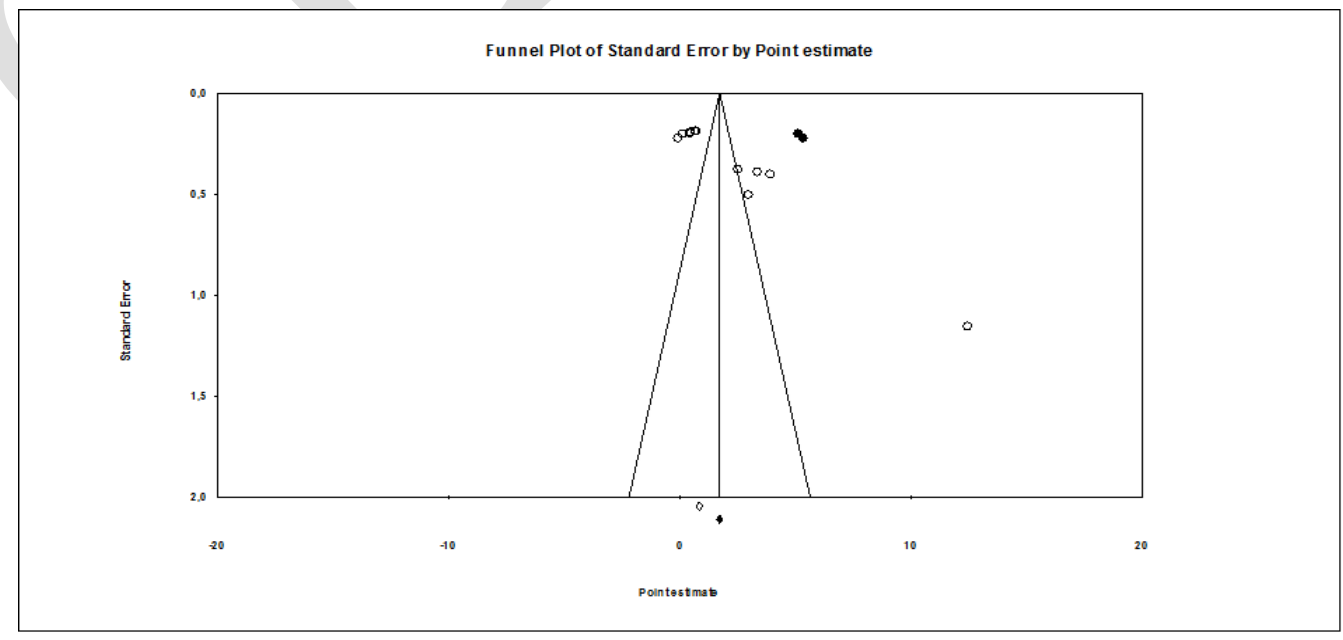

Şekil 2. Duval ve Tweedie'nin Kırp ve Doldur Yöntemi Kullanılarak Oluşturulan Huni Grafiği (Funnel Plot) Motivasyon 
Duval ve Tweedie'nin kırp ve doldur yöntemine göre; simetriyi sağlayabilmek için eklenmesi gereken yapay çalışma sayısının az olması yapılan meta analizin yayın yanlılığının da az olması anlamına gelmektedir. Burada huni grafiğe eklenen 2 adet çalışma, yapılan meta analizde yayın yanlılı̆̆ının olmadığını, olsa bile bu yanlılığın çok az olduğunu ifade etmektedir

Gerçekleştirilen meta-analiz çalışmasının yayın yanlılığı ile ilgili daha net ifadeler kullanabilmek için güvenli $\mathrm{N}$ istatistiğinden faydalanılmıştır. Rosenthal'e ait olan bu formül ile yapılan analizler neticesinde elde edilen sonuçlar aşağıdaki tabloda verilmiştir:

Tablo 3. Dijital Hikâye Yönteminin Öğrencilerin Motivasyonları Üzerindeki Etkisini Araştıran Meta-Analiz için Yapılan Rosenthal FSN Hesaplaması

Yanlılık Durumu
Gözlenen Çalışmalar İçin Z Değeri
Gözlenen Çalışmalar İçin P Değeri
Alfa
Yön

Alfa İçin Z Değeri

Gözlenen Çalışma Sayısı

FSN

16,15708
0.000
0.05
2

1.95996

11

737

Tablo 3'e göre hesaplanan güvenli N sayısı 737'dir. Bu sonuç, 2,070 olarak hesaplanan ortak etki büyüklügüünün istatistiksel açıdan anlamsız olabilmesi için sıfır etki düzeyine sahip 737 adet çalışmanın daha meta analize alınması gerektiğini ifade etmektedir. Bu sonuç, hesaplanan ortak etki büyüklüğü değerinin yayın yanlılığına karşı dirençli olduğunu göstermektedir.

Meta analiz sonuçlarının yayın yanlılığı Orwin'in güvenli $\mathrm{N}$ istatistiğine göre de incelenmiş ve elde edilen sonuçlara göre; 2,070 olarak hesaplanan ortak etki büyüklüğü değerinin istatistiksel açıdan anlamsız olabilmesi için sıfır etki düzeyine sahip 908 adet çalışmaya ihtiyaç olduğu görülmüştür. Orwin'in güvenli $N$ istatistiğinden elde edilen sonuçlarda yapılan meta analiz çalışmasının sonuçlarının yayın yanlılığına sahip olmadığını göstermektedir.

Çalışmanın yayın yanlılığı, Mullen, Muellerleile ve Bryant (2001)'ın, N/(5k+10) formülüne göre de analiz edilmiştir. İlgili hesaplamalar neticesinde $\left[737 /\left(5^{*} 11+10\right)=11,338\right]$ ortaya çıkan sonucun 1'den büyük olması, yapılan meta-analizin yayın yanlılığı taşımadığ1 şeklinde yorumlanabilir.

Gerçekleştirlen meta-analiz çalışmasının yayın yanlılığına sahip olmadığı farklı istatistiki yöntemlerle tespit edildikten sonra, dijital hikâye uygulamalarının öğrencilerin motivasyonları üzerindeki etkisini gösteren ortalama etki büyüklüğü değeri hesaplanmıştır.

İki farklı modelde (sabit etkiler modeli ve rastgele etkiler modeli) yapılabilen metaanaliz çalışmalarında kullanılacak modele karar verilirken meta analize dâhil edilen çalışmaların homojen yapıda mı yoksa heterojen yapıda mı olduğuna bakılır. Meta-analize alınan araştırmalar homojen yapıda ise sabit etkiler modeli, heterojen yapıda ise rastgele etkiler modeli kullanılır. Çalışmada hangi modelin kullanılacağına karar vermek için meta analiz kapsamına alınan 11 araştırmaya heterojenlik testi yapılmış ve ulaşılan sonuçlar Tablo 4 'te verilmiştir: 
Tablo 4. Sabit Etkiler Modeline Göre Ortalama Etki Büyüklükleri ve Güven Aralığı Alt-Üst Değerleri

\begin{tabular}{|c|c|c|c|c|c|c|c|c|}
\hline \multirow[t]{2}{*}{ Model } & \multirow[t]{2}{*}{$\begin{array}{l}\text { Ortalama } \\
\text { Etki } \\
\text { Büyüklüğü } \\
\text { Değeri (ES) }\end{array}$} & \multicolumn{2}{|c|}{$\begin{array}{c}\text { Etki } \\
\text { Büyüklüğ̈̈u } \\
\text { İçin \%95 } \\
\text { Güven Aralığ1 }\end{array}$} & \multirow[t]{2}{*}{$\begin{array}{l}\text { Standart } \\
\text { Hata } \\
\text { (SE) }\end{array}$} & \multirow[t]{2}{*}{$\begin{array}{c}\text { Homojenlik } \\
\text { Değeri }(Q)\end{array}$} & \multirow[t]{2}{*}{$\begin{array}{l}\text { df } \\
(Q)\end{array}$} & \multirow[t]{2}{*}{ p } & \multirow[t]{2}{*}{$\mathbf{I}^{2}$} \\
\hline & & $\begin{array}{l}\text { Alt } \\
\text { Sinir }\end{array}$ & $\begin{array}{l}\text { Üst } \\
\text { Sinir }\end{array}$ & & & & & \\
\hline $\begin{array}{l}\text { Sabit } \\
\text { Etkiler } \\
\text { Modeli }\end{array}$ & 0,835 & 0,688 & 0,983 & 0,075 & 275,782 & 10 & 0,000 & 96,374 \\
\hline
\end{tabular}

Tablo 4'e göre sabit etkiler modelinde gerçekleştirlen hesaplamalar sonucununda Q değeri 275,782 olarak tespit edilmiştir. $x^{2}$ tablosuna göre; \%95 anlamlılık düzeyinde 10 serbestlik derecesinin krtitik değeri 18,307'dir. Buna göre; $Q$ değerinin $(275,782) 10$ serbestlik derecesinin ki-kare dağllımının kritik değerinden ( $\mathrm{df}=10$ için $\left.\mathrm{x}^{2}=18,307\right)$ büyük olduğu görülmektedir. Tüm bunlar, meta-analize alınan çalışmaların heterojen bir yapıda olduğunu göstermektedir. Ayrıca \%96,374 olarak hesaplanan $\mathrm{I}^{2}$ değeri de meta analiz kapsamına alınan çalışmaların heterojen bir şekilde dağıldığına işaret etmektedir. Son olarak p değerinin 0,000 olduğu görülmektedir. p değerini 0.05 'ten küçük olması, meta-analiz kapsamında incelenen araştırmaların arasında anlamlı bir fark olduğunu göstermektedir. Böylelikle yapılacak meta-analize alınan çalışmaların heterojenliği, $\mathrm{p}$ değerinden yola çıkılarak gösterilmiştir. Meta-analize alınan çalışmaların heterojen yapıda olması, meta-analizin rastgele etkiler modeline göre hazırlanıp yorumlanması gerektiğini ortaya koymuştur.

Tablo 5. Rastgele Etkiler Modeline Göre Ortalama Etki Büyüklükleri ve Güven Aralığı Alt-Üst Değerleri

\begin{tabular}{|c|c|c|c|c|c|c|c|c|}
\hline \multirow[t]{2}{*}{ Model } & \multirow[t]{2}{*}{$\begin{array}{l}\text { Ortalama Etki } \\
\text { Büyüklüğü } \\
\text { Değeri (ES) }\end{array}$} & \multicolumn{2}{|c|}{$\begin{array}{c}\text { Etki Büyüklüğü } \\
\text { İçin \%95 Güven } \\
\text { Aralığı }\end{array}$} & \multirow[t]{2}{*}{$\begin{array}{l}\text { Standart } \\
\text { Hata (SE) }\end{array}$} & \multirow[t]{2}{*}{$\begin{array}{c}\text { Homojenlik } \\
\text { Değeri (Q) }\end{array}$} & \multirow[t]{2}{*}{$\begin{array}{l}\mathrm{df} \\
(\mathrm{Q})\end{array}$} & \multirow[t]{2}{*}{ p } & \multirow[t]{2}{*}{$\mathbf{I}^{2}$} \\
\hline & & $\begin{array}{l}\text { Alt } \\
\text { Sinir }\end{array}$ & $\begin{array}{l}\text { Üst } \\
\text { Sinir }\end{array}$ & & & & & \\
\hline $\begin{array}{c}\text { Rastgele } \\
\text { Etkiler } \\
\text { Modeli }\end{array}$ & 2,070 & 1,257 & 2,883 & 0,415 & 275,782 & 10 & 0,000 & 96,374 \\
\hline
\end{tabular}

Tablo 5 incelendiğinde rastgele etkiler modeline göre gerçekleştirilen analiz sonucunda ortalama etki büyüklüğü değeri (ES), 0,415 hata (SE) ile 2,070 olarak hesaplanmıştır. Etki büyüklüğünün \%95 güven aralığında alt sınırı 1,257, üst sınırı 2,883'tür. Bu sonuçlar, Cohen ve diğerlerine (2011) göre yorumlandığında, dijital hikâye etkinliklerinin öğrencilerin motivasyonlarını artırma noktasında mükemmel düzeyde bir etkiye sahip olduğunu göstermektedir. Ortalama etki büyüklüğü değerinin pozitif olması $(+2,070)$, işlemin deney grubu lehine olduğunu göstermektedir. Meta-analiz kapsamında etki büyüklüğü değeri hesaplanmış çalışmaların rastgele etkiler modeline göre oluşturulmuş dağılımını gösteren orman grafiği (forest plot) Şekil 3'te gösterilmiştir: 
Meta-Analiz (Motivasyon)

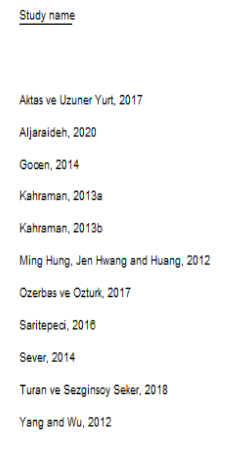

\begin{tabular}{|c|c|c|c|c|c|}
\hline \multirow[b]{2}{*}{$\begin{array}{l}\text { Point } \\
\text { estimate }\end{array}$} & \\
\hline & $\begin{array}{l}\begin{array}{c}\text { Standard } \\
\text { error }\end{array} \\
\text { eddar }\end{array}$ & Variance & $\begin{array}{l}\text { Lower } \\
\text { limit }\end{array}$ & $\begin{array}{l}\text { Upper } \\
\text { limit }\end{array}$ & Z.Value \\
\hline 12,431 & 1.154 & 1.332 & 10,189 & 14,693 & 10,770 \\
\hline 2,503 & 0,378 & 0,143 & 1,783 & 3,243 & 8,627 \\
\hline$-0,081$ & 0.224 & 0,050 & 0,520 & 0,368 & $-0,362$ \\
\hline 0,126 & 0.202 & 0.041 & $-0,270$ & 0.522 & 0,023 \\
\hline 0.448 & 0.200 & 0.040 & 0.058 & 0.840 & 2,240 \\
\hline 0,051 & 0,190 & 0,038 & 0,279 & 1,023 & 3,430 \\
\hline 2,968 & 0,504 & 0.254 & 1,970 & 3,946 & 5.870 \\
\hline 0.895 & 0.189 & 0.038 & 0.325 & 1.085 & 3.881 \\
\hline 3,345 & 0,390 & 0,152 & 2,580 & 4,110 & 8,587 \\
\hline 3,905 & 0,402 & 0,161 & 3,117 & 4,693 & 9,719 \\
\hline 0.488 & 0.193 & 0.037 & 0.089 & 0.847 & 2.421 \\
\hline 0.835 & 0.078 & 0.008 & 0.888 & 0.983 & 11.098 \\
\hline
\end{tabular}
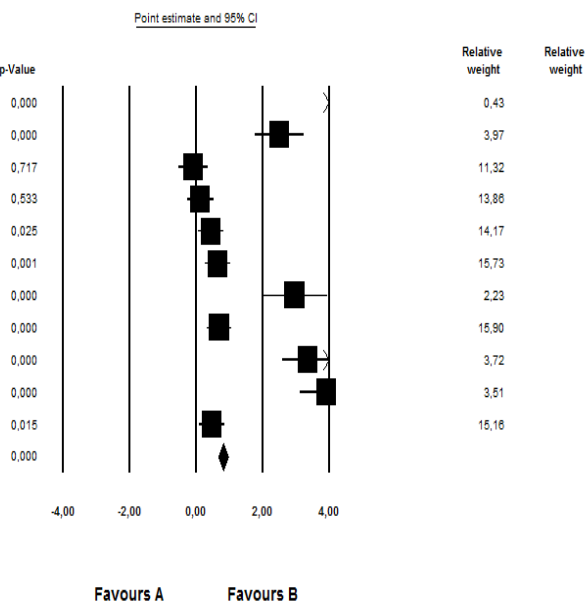

Şekil 3. Meta-Analiz Kapsamında Etki Büyüklüğü Değeri Hesaplanmış Çalışmaların Rastgele Etkiler Modeline Göre Oluşturulmuş Dağılımını Gösteren Orman Grafiği (Forest Plot)

Şekil 3'e göre güven aralığı en geniş olan çalışma Aktaş ve Uzuner Yurt (2017) iken güven aralığı en dar olan çalışma ise Sarıtepeci (2016)'dır. Çalışmaların meta-analiz sonucu üzerindeki ağırlıklarına ilişkin analizlerin sonucunda da en büyük ağırlığa sahip çalışmanın $\% 15,90$ oran ile Sarıtepeci (2016), en küçük ağırlığa sahip çalışmanın ise \%0,43 oran ile Aktaş ve Uzuner Yurt (2017) olduğu görülmektedir. Diğer çalışmalar ise, meta-analiz sonucu üzerinde çeşitli oranlarda ağırlık yüzdesine sahiptir.

Meta-analize alınan çalışmalar içerisinde en küçük etki büyüklüğü değerine sahip çalışma -0,081 ile Göçen (2014) iken en büyük etki büyüklüğü değerine sahip çalışma ise, 12,431 ile Aktaş ve Uzuner Yurt (2017)'dir. Etki büyüklüklerinin geneline bakıldığında ise, meta-analize alınan 11 çalışmanın 10'unun pozitif etkiye sahip olduğu görülmektedir. Bu durum, dijital hikâye yöntemi kullanılarak işlenen derslerin deney grupları lehine bir etki oluşturduğunu göstermektedir.

Dijital Hikâye Yönteminin Öğrencilerin Motivasyonları Üzerindeki Etkisinin Moderatör Değişkenlere Göre İncelenmesi

$\mathrm{Bu}$ bölümde, dijital hikâye ve diğer öğretim yöntemlerinin öğrencilerin motivasyonları üzerindeki etkilerinin karşılaştırıldığı araştırmaların meta analize tabi tutulması ile elde edilen etki büyüklüğü değerinin; yayın türü ve öğretim kademesine göre farklılaşıp farklılaşmadığı incelenmiştir.

$\mathrm{Bu}$ bağlamda ilk olarak yayın türü moderatör değişkeninin öğrencilerin motivasyonları üzerinde anlamlı bir fark oluşturup oluşturmadığı incelenmiş ve ilgili sonuçlar Tablo 6'da özetlenmiştir.

SEFAD, 2021; (46): 119-138 
Tablo 6. Dijital Hikâye Yönteminin Öğrencilerin Motivasyonları Üzerindeki Etkisinin Yayın Türü Moderatör Değişkenine Göre İncelenmesi

\begin{tabular}{|c|c|c|c|c|c|c|c|c|c|}
\hline \multirow[t]{2}{*}{$\begin{array}{l}\text { Yayın } \\
\text { Türü }\end{array}$} & \multirow[t]{2}{*}{$\mathbf{N}$} & \multirow[t]{2}{*}{$\begin{array}{l}\text { Ortalama } \\
\text { Etki } \\
\text { Büyüklüğü } \\
\text { Değeri (ES) }\end{array}$} & \multicolumn{2}{|c|}{$\begin{array}{c}\text { Etki } \\
\text { Büyüklüğü İçin } \\
\text { \%95 Güven } \\
\text { Aralığı }\end{array}$} & \multirow[t]{2}{*}{$\begin{array}{c}\text { Standart } \\
\text { Hata } \\
\text { (SE) }\end{array}$} & \multirow[t]{2}{*}{$\begin{array}{c}\text { Homojenlik } \\
\text { Değeri (Q) }\end{array}$} & \multirow[t]{2}{*}{$\begin{array}{l}\text { df } \\
(Q)\end{array}$} & \multirow[t]{2}{*}{$p$} & \multirow[t]{2}{*}{$\begin{array}{c}.05 \\
\text { Güven } \\
\text { Düzeyi } \\
X^{2}\end{array}$} \\
\hline & & & $\begin{array}{c}\text { Alt } \\
\text { Sinir }\end{array}$ & $\begin{array}{l}\text { Üst } \\
\text { Sinır }\end{array}$ & & & & & \\
\hline Makale & 6 & 3,431 & 1,856 & 5,006 & 0,804 & 8,264 & 1 & 0,004 & 3.841 \\
\hline $\begin{array}{c}\text { Lisansüstü } \\
\text { Tez }\end{array}$ & 5 & 0,847 & 0,057 & 1,636 & 0,403 & & & & \\
\hline
\end{tabular}

Tablo 6 incelendiğinde, yayın türü moderatör değişkeninin etki büyüklüğü değeri üzerinde anlamlı farklılığa sebep olduğu $(\mathrm{p}<.05)$ belirlenmiştir. Buna göre öğrencilerin motivasyonları; çalışmaların yayınlandığı yayın türüne göre farklılaşmaktadır. Ortak etki büyüklüğünün en yüksek olduğu yayın türü alanı 3,431 ile makale yayın türü iken tez yayın türünde ise etki büyüklügü $0,847^{\prime}$ dir. Hem makale hem de tez yayın türlerinde yayınlanan araştırmalara ait orta etki büyüklüğü değeri anlamlıdır ve elde edilen sonuçlar deney grubu lehinedir.

İkinci olarak öğretim kademesi moderatör değişkeninin öğrencilerin motivasyonları üzerinde anlamlı bir fark oluşturup oluşturmadığı incelenmiş ve ilgili sonuçlar Tablo 7'de özetlenmiştir.

Tablo 7. Dijital Hikâye Yönteminin Öğrencilerin Motivasyonları Üzerindeki Etkisinin Öğretim Kademesi Moderatör Değişkenine Göre İncelenmesi

\begin{tabular}{|c|c|c|c|c|c|c|c|c|c|}
\hline \multirow[t]{2}{*}{$\begin{array}{l}\text { Öğretim } \\
\text { Kademesi }\end{array}$} & \multirow[t]{2}{*}{$\mathbf{N}$} & \multirow[t]{2}{*}{$\begin{array}{l}\text { Ortalama } \\
\text { Etki } \\
\text { Büyüklüğ̈̈ } \\
\text { Değeri (ES) }\end{array}$} & \multicolumn{2}{|c|}{$\begin{array}{c}\text { Etki } \\
\text { Büyüklüğü İçin } \\
\text { \%95 Güven } \\
\text { Aralığı }\end{array}$} & \multirow[t]{2}{*}{$\begin{array}{c}\text { Standart } \\
\text { Hata } \\
\text { (SE) }\end{array}$} & \multirow[t]{2}{*}{$\begin{array}{c}\text { Homojenlik } \\
\text { Değeri }(Q)\end{array}$} & \multirow[t]{2}{*}{$\begin{array}{l}\text { df } \\
(Q)\end{array}$} & \multirow[t]{2}{*}{ p } & \multirow[t]{2}{*}{$\begin{array}{c}.05 \\
\text { Güven } \\
\text { Düzeyi } \\
X^{2}\end{array}$} \\
\hline & & & $\begin{array}{l}\text { Alt } \\
\text { Sinir }\end{array}$ & $\begin{array}{l}\text { Üst } \\
\text { Sinir }\end{array}$ & & & & & \\
\hline Ortaokul & 5 & 2,091 & 0,938 & 3,245 & 0,588 & 12,810 & 2 & 0,002 & 5.991 \\
\hline Lise & 3 & 0,352 & 0,127 & 0,576 & 0,115 & & & & \\
\hline Üniversite & & 5,030 & 0,717 & 9,342 & 2,200 & & & & \\
\hline
\end{tabular}

Tablo 7 incelendiğinde, öğretim kademesi moderatör değişkeninin etki büyüklüğü değeri üzerinde anlamlı farklılık yarattığı $(\mathrm{p}<.05)$ belirlenmiş̧tir. Buna göre öğrencilerin motivasyonları; öğrenim gördükleri öğretim kademesine göre farklılaşmaktadır. Ortak etki büyüklüğünün en yüksek olduğu öğretim kademesi üniversitedir. Onu sirasıyla ortaokul ve lise izlemektedir. Ortak etki büyüklükleri tüm öğretim kademelerinde anlamlı ve deney grubu lehinedir.

\section{SONUÇ}

Dijital hikâye yönteminin, öğrencilerin motivasyonları üzerindeki etkisini konu edinen bu meta-analizde, 11 araştırmanın etki büyüklüğü değeri hesaplanmıştır. Metaanalize alınan 11 çalışmanın 10'unun etki büyüklüğü değerinin pozitif olması, dijital hikâye uygulamalarının deney grubunda yer alan öğrencilerin lehine anlamlı bir farklılık oluşturduğunu göstermektedir. Bu sonuç; dijital hikâye etkinlikleri ile işlenen derslerdeki 
öğrencilerin motivasyonlarının, diğer öğretim yöntemine göre işlenen derslerdeki öğrencilerin motivasyonlarına göre daha yüksek olduğu anlamına gelmektedir. Buna göre, dijital hikâye yönteminin diğer öğretim yaklaşımlarına göre çok daha pozitif bir öğrenme ortamı sağladığı söylenebilir.

Meta analiz kapsamına dâhil edilen araştırmaların homonjenlik testi sonucunda elde edilen veriler, araştırmaların heterojen bir yapıya sahip olduklarını göstermiştir. Bu nedenle meta-analize alınan araştırmalar rastgele etkiler modeline göre incelenmiş ve 11 araştırmaya ait ortalama etki büyüklüğü değeri $+2,070$ olarak hesaplanmıştır. Bu değer, mükemmel düzeyde bir etkiye işaret etmektedir. Bu sonuçtan hareketle dijital hikâye yönteminin diğer öğretim yöntemlerine göre öğrencilerin motivasyonları üzerinde mükemmel düzeyde etkili olduğu söylenebilir. Etki büyüklügü değerinin yönünün pozitif olması, mükemmel düzeydeki bu etkinin derslerin dijital hikâye yöntemi ile işlendiği deney grubu öğrencilerinin lehine olduğunu göstermektedir.

Yapılan meta analiz neticesinde hesaplanan ortak etki büyüklüğü değerinin yayın yanlılığına sahip olup olmadığını tespit edebilmek için araştırma kapsamında incelenen çalışmaların huni grafikteki dağılımları incelenmiş ve çalışmaların birçoğunun huni grafiğinin dışında toplandığı tespit edilmiştir. Yayın yanlılığının olmaması için oluşturulan huni grafiğinin simetrik bir yapıya sahip olması beklenir. Burada oluşturulan grafik incelendiğinde huni grafiğin simetrik yapısını bozan bazı çalışmaların olduğu görülmüştür. $\mathrm{Bu}$ durum meta analiz sonuçlarının yayın yanlılığına sahip olabileceğini gösterir. Fakat bu konuda daha kesin sonuçlar elde edebilmek için yayın yanlılığı formülleri kullanılarak gerekli hesaplamalar yapılmış ve elde edilen sonuçlar, yapılan meta analizin yayın yanlılığına karşı dirençli olduğunu göstermiştir.

Dijital hikâye yönteminin öğrencilerin motivasyonları üzerindeki etkisini meta analiz kullanarak tespit etmeyi amaçlayan bu araştırmada, moderatör değişken olarak yayın türü ve öğretim kademesi değişkenleri belirlenmiştir. Öğrencilerin motivasyonları arasındaki farklılıklar bu moderatör değişkenlere göre analiz edilmiştir. Elde edilen sonuçlar; her iki değişkeninin de çalışmaların etki büyüklükleri üzerinde anlamlı bir fark oluşturduğunu göstermiştir.

Öğrencileri merkeze alan ve birden fazla duyu organını aynı anda harekete geçiren yapısıyla dijital hikâye yöntemi, çağdaş eğitim anlayışlarına uygun bir yöntem ve son dönemlerde üzerinde çokça araştırma yapılan bir konu alanı olarak karşımıza çıkmaktadır. Dijital hikâyenin, öğrencilerin motivasyonları üzerinde mükemmel düzeyde ve pozitif bir etkiye sahip olması, bu yöntemin okullarda farklı branş derslerinin öğretiminde kullanılması gerekliliğini de ortaya koymaktadır. Farklı yöntem ve tekniklerle harmanlanmış ve zenginleştirilmiş dijital hikâye uygulamalarının, öğrencilerin motivasyonları üzerinde çok daha pozitif etkiler oluşturacağı aşikârdır.

Alanyazın incelendiğinde dijital hikâye uygulamalarının öğrencilerin motivasyonlarına olan genel etkisinin araştırıldığı meta-analiz çalışmalarının yapılmadığı görülmüştür. $\mathrm{Bu}$ meta analiz çalışması, alanyazındaki eksikliği bir noktaya kadar giderebilecektir ve dijital hikâye uygulamalarının öğrencilerin farklı duyuşsal becerileri (güdülenme, konsantrasyon, direnç $v b$.) üzerindeki etkilerini araştıran başka meta analiz çalışmalarına da yol açacaktır.

SEFAD, 2021; (46): 119-138 
Dijital hikâye ve artırılmış gerçeklik gibi öğrencileri merkeze alan ve onları teknoloji ile bir araya getiren yöntemlerin okullarda kullanımı çağdaş eğitim sistemlerinde büyük önem arz etmektedir. Bu nedenle öğretmenlerin dijital hikâye ve artırılmış gerçeklik gibi modern öğretim yöntemleri konusunda kendilerini geliştirmelerinin önemli olduğu düşünülmektedir. Eğitim öğretim süreçlerinden sorumlu kurumların ise, öğretmenleri bu doğrultuda yetiştirecek hizmetiçi eğitimlere ve kurslara yer vermeleri ve öğretmenlere bu bağlamda fırsatlar sunmaları gerekmektedir. Ayrıca geleceğin öğretmenleri olan eğitim fakültesi öğrencilerinin de bu alandaki eksikliklerini gidermek için gerekli derslere müfredatta yer verilmesi bu bağlamda önemli bir adım olarak görülmektedir.

\section{SUMMARY}

\section{Introduction}

The digital story, arising out of the cohesion of traditional storytelling and computer technologies, has started to be used actively in education processes just like in many other fields. The digital story method, which aims to create a student-centered education model by enabling the student to become active, is an important method that increases student participation, provides deep and project-based learning, makes learning more permanent and provides technology integration to the learning environment (Çakıcl, 2018 and Barret, 2009). All of these are also noteworthy in terms of showing the positive effects of the use of digital stories on students in educational processes.

It is emphasized that in many studies on the digital story method, this method increases students' interests, attitudes, and motivations towards the course. It is also natural that students who have the opportunity to write their own stories and share them with others have a positive attitude and motivation towards this class. In this context, the purpose of this meta-analysis study is stated as determining the effect of classes taught using digital story-based activities on students' motivations.

\section{Method}

In this study, the meta-analysis method was used to synthesize the results of experimental studies that investigated the effect of digital story-based activities on students' motivations. The research data were gathered on April 2020 by using the ULAKBIM TR Index, ERIC, Web of Science, EBSCOhost, Google Academic and YOK (Council of Higher Education) Thesis databases, using the keywords "dijital hikâye, dijital öykü, motivasyon, digital story, digital storytelling, and motivation". The Comprehensive Meta-Analysis (CMA) software was used in all the analyses required throughout the research.

\section{Conclusion and Recommendations}

In this study, which investigates the effect of classes taught with the digital story method on students' motivations, the effect size values of 11 studies within the scope of meta-analysis were calculated. It was determined that the effect size value of all 11 studies included in meta-analysis was positive. This indicates that the digital story method makes a significant difference in favor of the experimental group.

The data obtained as a result of the homogeneity test of the studies included in the scope of meta-analysis showed that the studies have a heterogeneous structure. For this reason, the studies included in the study were analyzed according to the random effects 
model, and the average effect size value of 11 studies was calculated as $+2,070$. This value indicates a excellent effect when interpreted according to Cohen et al. (2011).

In this study, which aims to determine the effect of digital story method on students' motivations by using meta-analysis, the type of publication and teaching level were determined as the moderator variables. The differences between students' motivations were analyzed according to these moderator variables. Obtained results showed that both variables made a significant difference on the effect sizes of the studies.

Makale Bilgileri

Etik Kurul Kararı: $\quad$ Çalışma, Ağrı İbrahim Çeçen Üniversitesi'nin 18.06.2020 tarihli ve 90 onay numaralı kararı ile Etik Onay almıştır.

Katılımcı Rızası: Araştırmaya katılanlara çalışmanın amacı ifade edilerek rızaları alınmıştır.

Mali Destek: Çalışma için herhangi bir kurum ve projeden mali destek alınmamıştır.

Çıkar Çatışması: $\quad$ Çalışmada kişiler ve kurumlar arası çıkar çatışması

Telif Haklarn: bulunmamaktadır.

Article Information

Telif hakkı sahiplerinden gerekli izinler alınmıştır.

Ethics Committee Approval: The study received Ethical Approval from Agri Ibrahim Cecen University with the approval number of 90 and the date of 18.06.2020.

Informed Consent: The purpose of the study is explained to the particants and their informed consent was obtained.

Financial Support: Conflict of Interest: No financial support from any institution or project. No conflict of interest. Copyrights: The required permissions have been obtained from the copyright holders. 


\section{KAYNAKÇA}

*Meta-analize dâhil edilen çalışmalar

*Aktas, E. \& Uzuner Yurt, S. (2017). Effects of Digital Story on Academic Achievement, Learning Motivation and Retention among University Students. International Journal of Higher Education, 6(1): 180-196.

*Aljaraideh, Y. A (2020). The impact of digital storytelling on academic achievement of sixth grade students in English language and their motivation towards it in Jordan. Turkish Online Journal of Distance Education-TOJDE, 21(1): 73-82.

Alyılmaz, C. (1997). Teknoloji ve dil. Atatürk Üniversitesi Türkiyat Araştırmaları Enstitüsü Dergisi, 8, 33-36.

Bakioğlu, A. \& Özcan, Ş. (2016). Meta-analiz. Ankara: Nobel Akademik Yayıncılık.

Balaman, F. (2016). The effect of digital storytelling technique on the attitudes of students toward teaching technologies. Pegem Eğitim ve Öğretim Dergisi, 6(2), 147-168, http://dx.doi.org/10.14527/pegegog.2016.009.

Banaszewski, T. M. (2005). Digital storytelling: supporting digital literacy in grades 4-12 (Yayımlanmamış Yüksek Lisans Tezi), Georgia Institute of Technology, Atlanta.

Barret, H.C. (2009). How to create simple digital stories. 17.05.2020. https://electronicportfolios.org/digistory/howto.html

Bull, G. \& Kajder, S. (2004). Digital storytelling in the language arts classroom. Learning $\mathcal{E}$ Leading with Technology, 32(4), 46-49.

Center for Digital Storytelling Website. (2020, 13 Nisan). [Çevrim-içi: http://www.storycenter.org/history/] Erişim tarihi: 13 Nisan 2020.

Chung, S. K. (2007). Art education technology: Digital Storytelling. Art Education, (602), 1722.

Cohen, L., Manion, L. \& Morrison, K. (2011). Research methods in education (7. bs.). New York: Routledge.

Çakıcı, L. (2018). Dijital öykü temelli matematik öğretiminin öğrencilerin akademik başarı motivasyon ve matematik etkinliklerine yönelik tutumlar üzerine etkisi (Yayınlanmamış Yüksek Lisans Tezi), Gaziantep Üniversitesi Eğitim Bilimleri Enstitüsü, Gaziantep.

Dinçer, S. (2014). Ĕ̆itim bilimlerinde uygulamalı meta-analiz. Ankara: Pegem Akademi.

Dörner, R., Grimm, P. \& Abawi, D. F. (2002). Synergies between interactive training simulations and digital storytelling: a component-based framework. Computers $\mathcal{E}$ Graphics, 26(1), 45-55.

Durlak, J. A. \& Lipsey, M. W. (1991). A practitioner's guide to meta-analysis. American Journal of Community Psychology, 19(3), 291-332.

Frazel, M. (2010). Digital storytelling guide for educators. Washington, DC: International Society for Technology in Education.

Garcia, P. \& Rossiter, M. (2010). Digital storytelling as narrative pedagogy. Proceedings of society for information technology \& teacher education international conference, 1091-1097.

*Göçen, G. (2014). Dijital öyküleme yönteminin öğrencilerin akademik başarıları ile öğrenme ve ders çalışma stratejilerine etkisi (Yayımlanmamış Yüksek Lisans Tezi), Muğla Sıtkı Koçman Üniversitesi, Muğla. 
Haliloğlu Tatlı, Z. (2016). Dijital öyküleme. A. İşman, H. F. Odabaşı ve B. Akkoyunlu (Eds.), Eğitim Teknolojileri Okumaları 2016 içinde (ss. 219-236). Ankara: Salmat Basım Yayıncılık.

Hedges, L. V. (2007). Meta-analysis. C. R. Rao ve S. Sinharay (Ed.), Handbook of statistics 26: Psychometrics içinde (s. 919-953). Oxford: Elsevier

Howell, D. \& Howell, D. (2003). What is your digital story? Library Media Connection, 22/2, p40,2p.

https://campbellcollaboration.org/research-resources/effect-size-calculator.html https://www.psychometrica.de/effect_size.html

*Hung, C. M., Hwang, G. J. \& Huang, I. (2012). A project-based digital storytelling approach for improving students' learning motivation, problem-solving competence and learning achievement. Educational Technology \& Society, 15(4), 368-379.

İnceelli, A. (2005). Dijital hikâye anlatımının bileşenleri. The Turkish Online Journal of Educational Technology, 4(3), 132-142.

Jakes, D. S \& Brennan, J. (2005). Capturing Stories, Capturing Lives: An Introduction to Digital Storytelling. Retrieved April 28, 2020, from http://www.jakesonline.org/dst_techforum.pdf

*Kahraman, Ö. (2013). Dijital hikâyecilik metoduyla hazırlanan öğretim materyallerinin öğrenme döngüsü giriş aşamasında kullanılmasının fizik dersi başarısı ve motivasyonu düzeyine etkisi (Yayınlanmamış Doktora Tezi). Balıkesir Üniversitesi Fen Bilimleri Enstitüsü, Balıkesir.

Lambert, J. (2003). Digital storytelling cookbook and traveling companion. Berkeley, CA: Digital Diner.

Lambert, J. (2006). Digital storytelling cookbook (2nd ed.). Berkeley, CA: Digital Diner Press. Retrieved from http://redcrossyouth.org/wp-content/uploads/2012/03/cdscookbook.pdf

Lipsey, M. W. \& Wilson, D. B. (2001). Practical meta-analysis. USA: Sage Publications.

Meadows, D. (2003). Digital Storytelling-Research-based Practice in New Media. Visual Communication, 2(2), 189-193.

Mellon, C. A. (1999). Digital storytelling: Effective learning through the internet. Educational Technology, 39(2), 46-50.

Menezes, H. (2012). Using digital storytelling to improve literacy skills. Paper presented at the International Conference on Cognition and Exploratory Learning in Digital Age. Retrieved from ERIC database. (ED542821)

Miles, M. B. \& Huberman, A.M. (1994). Qualitative data analysis: An expanded sourcebook. (2nd Edition). Calif. : SAGE Publications.

Mullen, B., Muellerleile, P. \& Bryant, B. (2001). Cumulative meta-analysis: A consideration of indicators of sufficiency and stability. Personality and Social Psychology Bulletin, 27(11), 1450-1462.

Ohler, J. (2013). Digital storytelling in the classroom. New media pathways to literacy, learning, and creativity. (2nd ed.). Thousand Oaks, CA: Sage Publications.

*Özerbaş, M. A. \& Öztürk, Y. (2017). Türkçe dersinde dijital hikâye kullanımının akademik başarı, motivasyon ve kalıcılık üzerinde etkisi. TÜBAV Bilim, 10(2): 102-110.

SEFAD, 2021; (46): 119-138 
Reinders, H. (2011). Digital storytelling in the foreign language classroom. ELTWO Journal, 3 , 1-9. Retrieved from http://blog.nus.edu.sg/eltwo/2011/04/12/digitalstorytelling-in-theforeign-language-classroom-2/

Robin, B. R. (2006). The educational uses of digital storytelling. [Online].(12.05.2020), http://digitalstorytelling.coe.uh.edu/articles/Educ-Uses-DS.pdf

Robin, B. R. \& Pierson, M. E. (2005). A multilevel approach to using digital storytelling in the classroom. Society for Information Technology \& Teacher Education International Conference. Phoenix, AZ, USA, $2005 . \quad$ [Çevrim-içi: http://faculty.coe.uh.edu/brobin/homepage/SITE2005-article.htm], Erişim Tarihi: 15 Nisan 2020.

Salkind, N. J. (2007). Encyclopedia of measurement and statistics. California: SAGE Publications.

*Sarıtepeci, M. (2016). Dijital hikâye anlatım yönteminin sosyal bilgiler dersinde etkililĭğinin incelenmesi (Yayınlanmamış Doktora Tezi). Gazi Üniversitesi Eğitim Bilimleri Enstitüsü, Ankara.

Schulze, R. (2007). The state and the art of meta-analysis. Zeitschrift für Psychologie / Journal of Psychology, 215(2), 87-89.

*Sever, T. (2014). An investigation into the impact of digital storytelling on the motivation level of students (Unpublished Master of Academic Thesis), Çanakkale Onsekiz Mart Unıversıty Institute Of Educational Sciences, Çanakkale.

*Turan, T. \& Şeker Sezginsoy, B. (2018). The effect of digital stories on fifth-grade students' motivation. Journal of Education and Future, 13, 65-78.

*Yang, Y.-T. C. \& Wu, W.-C. I. (2012). Digital storytelling for enhancing student academic achievement, critical thinking and learning motivation: A year-long experimental study. Computers and Education, 59, 339-352.

Yüksel, P. (2011). Okul öncesi eğitiminde dijital öykü anlatımının kullanılması (Yayımlanmamış Doktora Tezi). Orta Doğu Teknik Üniversitesi, Fen Bilimleri Enstitüsü, Ankara. 